\title{
Hubungan Model Pembelajaran Kooperatif Tipe Numbered Head Together (NHT) terhadap Minat dan Hasil Belajar Siswa di Kelas VII SMP Negeri 4 Kota Bima Tahun Pelajaran 2021/2022
}

\author{
Pri Ayu Nurwadani ${ }^{1}$, Syarifuddin $^{2 *}$, Gunawan $^{2}$, Dusalan $^{2}$ \\ ${ }^{1}$ Mahasiswa Prodi Pendidikan Matematika, STKIP Bima, Kota Bima, Indonesia \\ ${ }^{2}$ Dosen Prodi Pendidikan Matematika, STKIP Bima, Kota Bima, Indonesia \\ *Coresponding Author: syarifuddin.stkipbima@gmail.com
}

\begin{tabular}{ll}
\hline \hline Article history & Penelitian ini bertujuan untuk mengetahui minat belajar, hasil \\
Dikirim: & belajar, dan mengetahui seberapa besar hubungan minat belajar \\
& dan hasil belajar siswa. Pelaksanaan pembelajaran pada penelitian \\
Direvisi: & ini merupakan model pembelajaran kooperatif tipe Numbered \\
09-12-2021 & Heads Together (NHT) pada materi himpunan. Tempat penelitian \\
Diterima: & ini dilaksanakan di SMPN 4 Kota Bima yang terdiri dari 1 kelas. \\
11-12-2021 & Intrumen penelitian dengan menggunakan angket minat dan tes \\
& hasil belajar. Analisis data menggunakan analisis korelasional. \\
Key words: & Hasil penelitian ini menunjukan: 1) minat belajar siswa kelas VII- \\
\hline Pembelajaran Kooperatif & B SMP Negeri 4 Kota Bima masuk dalam kategori tinggi, karena \\
Belajar; Siswa SMP & jumlah siswa yang masuk dalam kategori bermotivasi sangat \\
& tinggi, tinggi, dan sedang adalah 60\% dari total keseluruhan 35 \\
& siswa; 2) hasil belajar siswa kelas VII-B SMP Negeri 4 Kota \\
& Bima masuk dalam kategori rendah, karena jumlah siswa yang \\
& masuk dalam kategori bermotivasi rendah dan sangat rendah \\
& adalah 60\% dari total keseluruhan 35 siswa; dan 3) Berdasarkan \\
& perhitungan yang telah dilakukan, koefisien korelasi yang \\
& diperoleh sebesar 0,142. Hal ini menunjukkan ada korelasi antara \\
& minat belajar siswa terhadap hasil belajar siswa tetapi tidak \\
& signifikan. Kontribusi minat belajar terhadap hasil belajar yang \\
& diperoleh adalah 0,142 = 0,020164 atau 2,0164\%. \\
\hline \hline
\end{tabular}

\section{PENDAHULUAN}

Pendidikan merupakan salah satu bentuk perwujudan kebudayaan manusia yang dinamis. Pendidikan hendaknya mempersiapkan siswa di masa yang akan datang sehingga siswa dapat menyelesaikan masalah- masalah yang dihadapi dalam kehidupan sehari-hari. Dengan demikian, siswa dapat melangsungkan kehidupannya dalam hidup bermasyarakat. sekolah merupakan salah satu tempat siswa mendapatkan pendidikan. Kegiatan-kegiatan yang dilaksanakan di sekolah sebagian besar bertujuan untuk mendidik siswa.

Belajar dan mengajar merupakan salah satu kegiatan yang dilakukan di sekolah. Menurut Winkel (1983), belajar merupakan suatu aktivitas mental/psikis, yang berlangsung dalam interaksi aktif dengan lingkungan, yang menghasilkan perubahan-perubahan dalam pengetahuan-pemahaman, keterampilan dan nilai-sikap. Perubahan itu bersifat secara relatif konstan dan berbekas. Dengan demikian, peserta didik dikatakan belajar apabila peserta didik melakukan kegiatan interaksi aktif dengan lingkungan sehingga memperoleh pengetahuan, keterampilan, serta nilai sikap. Mengajar adalah untuk melihat bagaimana proses belajar berjalan. Tidak 
hanya sekedar mengatakan dan memberikan instruksi atau tidak hanya membiarkan siswa belajar sendiri.

Mengajar sebenarnya memberi kesempatan kepada yang diajar untuk mencari, bertanya, menalar dan bahkan menebak dan mendebat. Oleh karena itu, mengajar bukan sekedar menyampaikan materi saja melainkan memberikan kesempatan kepada siswa untuk mengembangkan idenya.

Minat memiliki kaitan yang erat terhadap hasil belajar yakni siswa yang menyukai matematika akan merasa senang belajar matematika sehingga terdorong untuk belajar lebih giat, demikian sebaliknya. Menurut Mudjiono \& Dimyati (2006) mengemukakan bahwa hasil belajar mempunyai kaitan yang erat dengan minat. Siswa yang memiliki minat terhadap suatu bidang studi tertentu cenderung tertarik perhatiannya dan dengan demikian timbul minat belajar untuk mempelajari bidang studi tersebut. Minat belajar juga dipengaruhi oleh nilai-nilai yang dianggap penting untuk kehidupannya. Perubahan nilai-nilai yang dianut akan mengubah tingkah laku manusia dan hasil belajarnya.

Salah satu upaya yang dapat dilakukan dalam mengatasi permasalahan mengenai rendahnya minat dan hasil belajar belajar siswa yakni dengan menerapkan model pembelajaran kooperatif. Pembelajaran ini muncul dari konsep bahwa siswa akan lebih mudah menemukan dan memahami konsep yang sulit jika mereka saling berdiskusi dengan temannya. Hasil wawancara yang dilakukan dengan guru matematika di SMP Negeri 4 Kota Bima dengan Pak Jainul Arifin diperoleh fakta bahwa pelajaran matematika masih belum mendapatkan tempat di hati para siswa. Hal ini terbukti pada hasil ulangan harian kelas VII SMPN 4 Kota Bima, yang menyatakan bahwa nilai tertinggi ulangan harian matematika siswa adalah 85 , nilai terendahnya adalah 35, sedangkan rata-ratanya adalah 55. Hasil itu menunjukkan kategori sedang yang tentunya belum memenuhi Kriteria Ketuntasan Minimal (KKM) yang ditetapkan yaitu 60. Pada umumnya para siswa menganggap pelajaran matematika sebagai pelajaran yang sulit dipahami. Dengan keadaan yang demikian dan kurang tertariknya siswa terhadap pelajaran matematika mengakibatkan minat dan hasil belajar matematika sering rendah.

Berdasarkan hasil observasi, guru memilih model pembelajaran dengan menerapkan metode ceramah. Pada awal pembelajaran dimulai, guru tidak melakukan tanya jawab mengenai materi sebelumnya kepada siswa guna mengetahui pengetahuan awal siswa maupun memancing siswa untuk aktif. Namun, apabila dipertemuan sebelumnya guru memberikan tugas maka pada pertemuan selanjutnya guru membahas tugas tersebut diawal pembelajaran. Tidak semua tugas yang diberikan dibahas oleh guru, melainkan hanya soal-soal tertentu saja yakni soal yang dianggap sulit diselesaikan oleh siswa. Biasanya guru berkeliling untuk mengecek pekerjaan yang dikerjakan siswa dan memberi teguran kepada siswa yang tidak mengerjakan tugas. Dalam membahas tugas tersebut, guru tidak menunjuk salah satu siswa untuk mengerjakan di papan tulis melainkan menawarkan siapa yang bersedia untuk mengerjakan dipapan tulis, jika tidak ada yang bersedia maka guru akan menunjuk salah satu siswa untuk menuliskan hasil pekerjaannya. Salah satu siswa maju untuk menuliskan hasil pekerjaannya, siswa yang bersedia biasanya siswa yangduduk di barisan depan atau tengah. Kemudian guru memberikan penjelaskan serta pembenaran terkait hasil pekerjaan siswa. 
Cara guru menyampaikan materi sudah baik, hal ini terlihat dari penyampaian materi yang terstruktur. Namun, selama proses pembelajaran berlangsung guru menjelaskan materi di depan kelas dan siswa hanya mendengarkan penjelasan dari guru sehingga proses pembelajaran yang berlangsung berpusat pada guru. Selain itu, siswa mencatat apa yang ditulis oleh guru di papan tulis serta siswa cenderung tidak bertanya. Terlihat kegiatan siswa tersebut hanya disibukkan dengan mencatat bukan mengembangkan ide yang dapat berupa berpendapat maupun bertanya. Ketika guru menyampaikan materi, tidak sedikit siswa yang tidak memperhatikan penjelasan dari guru. Hal tersebut ditandai dengan adanya siswa khususnya siswa yang berada pada berisan belakang asyik mengobrol dengan teman didekatnya sehingga membuat gaduh kelas. Ketika mereka ditegur oleh guru, mereka pun diam tetapi tak lama kemudian mereka kembali mengobrol dan kelas menjadi gaduh kembali. Selain itu, siswa yang duduk didekat tembok, kurang memperhatikan guru yang sedang menjelaskan materi melainkan biasanya ia duduk bersandar pada tembok dan hanya melihat ke arah teman-teman satu kelas bahkan mereka terlihat berkomunikasi dengan teman yang duduknya berjauhan mengenai hal lain yang tidak terkait denganmateri.Selama proses pembelajaran berlangsung, adakalanya guru jalan berkeliling untuk mengecek catatan maupun pekerjaan siswa.

Dengan demikian, terlihat bahwa strategi yang digunakan oleh guru dalam menyampaikan materi dirasa masih kurang cocok dengan kebutuhan dan karakteristik siswa. Ketika proses pembelajaran berlangsung penting adanya interaksi antara guru dengan siswa. Namun kenyataanya kegiatan pembelajaran tersebut berpusat pada guru, sehingga menjadikan siswa cenderung pasif dan hanya sibuk dengan kesibukannya masing-masing. Dapat dilihat interaksi antara guru dan siswa kurang terjalin dengan baik. Hal ini dapat ditandai dengan adanya siswa yang tidak memperhatikan penjelasan guru karena asyik mengobrol ketika proses pembelajaran berlangsung. Kondisi tersebut dapat mengindikasikan rendahnya minat dan hasil belajar siswa pada pembelajara matematika.

Untuk mengatasi situasi di atas, guru harus memiliki kecakapan dan keterampilan dalam menyajikan pelajaran kepada siswa yang dapat menarik dan memfokuskan perhatiannya, agar pembelajaran matematika dapat diikuti oleh siswa dengan minat dan keaktifan yang baik serta rasa kerja sama sehingga mampu berpengaruh terhadap hasil belajar matematika siswa. Oleh karena itu, diperlukan adanya penggunaan model pembelajaran yang tepat dan sesuai dengan materi yang diajarkan. Salah satunya adalah model pembelajaran kooperatif tipe Number Head Together (NHT).

Dengan demikian, dalam proses pembelajaran berlangsung dapat digunakan model pembelajaran kooperatif tipe Numbered Head Together (NHT) untuk mengatasi persoalan tersebut. Pembelajaran Kooperatif tipe Numbered Head Together (NHT) ini memberikan kesempatan kepada siswa untuk saling sharing ideide dan mempertimbangkan jawaban yang paling tepat serta dapat meningkatkan semangat kerjasamasiswa.

\section{KAJIAN TEORI}

\section{Hakikat Hasil Belajar Matematika}


Belajar adalah suatu aktivitas yang dilakukan untuk memperoleh suatukonsep, pemahaman, atau pengetahuan baru sehingga memungkinkan terjadinya perubahan perilaku. Hasil belajar dapat dijelaskan dengan memahami dua kata yaitu hasil dan belajar. Secara sederhana, yang dimaksud dengan hasil belajar siswa adalah kemampuan yang diperoleh anak setelah melalui kegiatan belajar (Susanto, 2013). Jadi dapat disimpulkan bahwa hasil belajar merupakan kemampuan yang dimiliki siswa baik itu kognitif, afektif maupun psikomotorik yang dimiliki siswa setelah mengikuti proses belajar mengajar. Ini berasrti hasil belajar tergantung pada proses pembelajaran. Untuk menyatakan bahwa suatu proses belajar mengajar dapat dikatakan berhasil, setiap guru memiliki pandangan masing-masing sejalan dengan pemikirannya.

Sejalan dengan itu, dalam sistem pendidikan nasional rumusan tujuan pendidikan, baik tujuan kurikuler maupun tujuan instruksional, menggunakan klasifikasi hasil belajar yang secara garis besar terbagi menjadi tiga ranah, yaitu :

1. Ranah Kognitif berkenaan dengan hasil belajar intelektual yang terdiri dari enam aspek, yakni pengetahuan atau ingatan, pemahaman, aplikasi, analisis, sintesis, dan evaluasi.

2. Ranah Afektif berkenaan dengan sikap yang terdiri dari lima aspek, yakni penerimaan, jawaban atau reaksi, penilaian, organisasi, dan internalisasi.

3. Ranah psikomotoris berkenaan dengan hasil belajar keterampilan dan kemampuan bertindak.

Di dalam ketiga ranah tersebut terdapat beberapa aspek dan dijadikan sebagai objek penilaian hasil belajar. Matematika merupakan suatu ilmu dari serangkaian mata pelajaran yang mempunyai peranan penting dalam menunjang ilmu pengetahuan dan teknologi.

Matematika berasal dari akar kata mathema artinya pengetahuan, mathanein artinya berpikir atau belajar. Dalam kamus Bahasa Indonesia diartikan matematika dalah ilmu tentang bilangan hubungan antara bilangan dan prosedur operasional yang digunakan dalam penyelesain masalah mengenai bilangan (Muhlisrarini \& Ali, 2014)

Berdasarkan uraian di atas dapat disimpulkan bahwa matematika adalah bekal bagi peserta didik untuk berpikir logis, analitis, sistematis, kritis dan kreatif. Mempelajari matematika sebagai suatu ilmu pengetahuan yang berhubungan langsung dengan kehidupan sehari-hari yang akan mendapatkan ilmu pengetahuan yang sangat berguna bagi kehidupan.

\section{Model Pembelajaran Kooperatif (Cooperatif Learning)}

Pembelajaran kooperatif merupakan suatu model pembelajaran yang mengutamakan adanya kelompok-kelompok. Pembelajaran Kooperatif (Cooperatif Learning) adalah strategi pembelajaran yang menekankan proses bekerja sama dalam suatu kelompok yang bisa terdiri dari 2 sampai 6 orang siswa untuk mempelajari suatu akademikyang spesifik sampai tuntas (Sanjaya, 2011).

Pembelajaran kooperatif adalah suatu sistem yang didasarkan pada alasan bahwa manusia sebagai makhluk individu yang berbeda satu sama lain sehingga konsekuensi logisnya menusia harus menjadi makhluk sosial, makhluk yang berinteraksi dengan sesama.

Dengan demikian pembelajaran kooperatif, dapat disimpulkan bahwa pembelajaran kooperatif merupakan suatu model pembelajaran yang dilakukan secara berkelompok, dimana setiap siswa memiliki tanggung jawab baik secara 
individu maupun kelompok terhadap keberhasilan belajar siswa yang dikembangkan melalui interaksi-interaksi yang terjadi antar anggota kelompok selama proses pembelajaran.

\section{Langkah-langkah Pembelajaran Kooperatif (Cooperatif Learning)}

Sanjaya (2011) mengatakan prosedur atau langkah-langkah pembelajaran kooperatif pada prinsipnya terdiri dari atas empat tahap, yaitu: 1) Penjelasan materi; 2) Belajar dalam kelompok; 3) Penialian; 4) Pengakuan tim

Menurut Mulyo \& Daryanto (2012), Langkah-langkah model pembelajaran kooperatif. Langkah indikator tingkah laku guru:

1) Guru menyampaikan tujuan pembelajaran dan mengkomunikasikankompetensi dasar yang akan dicapai serta memotivasi siwa.

2) Menyajikan informasi.

3) Mengorganisasikan siswa ke dalam kelompok-kelompok belajar.

4) Membimbing kelompok belajar serta memfasilitasi kerja siswa dalam kelompok belajar.

5) Guru mengevaluasi hasil belajar tentang materi pembelajaran yang telah dilaksanakan.

6) Memberikan penghargaan.

Secara umum, yang dikemukakan oleh Zubaedi (2011) pembelajaran memiliki sintaks atau langkah-langkahpembelajaran sebagai berikut

Tabel 1. Sintaks Model Pembelajaran Kooperatif

\begin{tabular}{|c|c|}
\hline Fase-Fase & Perilaku Guru \\
\hline $\begin{array}{l}\text { Fase 1: Present goals and set } \\
\text { Menyampaikan tujuan dan } \\
\text { mempersiapkan peserta didik }\end{array}$ & $\begin{array}{l}\text { Menjelaskan tujuan pembelajaran dan } \\
\text { mempersiapkan peserta didik siap belajar }\end{array}$ \\
\hline $\begin{array}{l}\text { Fase 2: Present information } \\
\text { Menyajikan informasi }\end{array}$ & $\begin{array}{l}\text { Mempresentasikan informasi kepada } \\
\text { peserta didik secara verbal }\end{array}$ \\
\hline $\begin{array}{l}\text { Fase 3: Organize student into } \\
\text { learning teams } \\
\text { Mengorganisir peserta didik ke } \\
\text { dalam tim-tim belajar }\end{array}$ & $\begin{array}{l}\text { Memberikan penjelasan kepada peserta } \\
\text { didik tentang tata cara pembentukan tim } \\
\text { belajar dan membantu kelompok } \\
\text { melakukan transisi yang efesien }\end{array}$ \\
\hline $\begin{array}{l}\text { Fase 4: Assist team work and } \\
\text { study } \\
\text { Membantu Kerja tim dan } \\
\text { belajar }\end{array}$ & $\begin{array}{l}\text { Membantu tim-tim belajar selama } \\
\text { peserta didik mengerjakan tugasnya }\end{array}$ \\
\hline $\begin{array}{l}\text { Fase 5: Test on the materials } \\
\text { Mengevaluasi }\end{array}$ & $\begin{array}{l}\text { Menguji pengetahuan peserta didik } \\
\text { mengenai berbagai materi pembelajaran } \\
\text { atau kelompok-kelompok } \\
\text { mempresentasikan hasil kerjanya }\end{array}$ \\
\hline $\begin{array}{l}\text { Fase 6: Provide recognition } \\
\text { Memberikan pengakuan atau } \\
\text { penghargaan }\end{array}$ & $\begin{array}{l}\text { Mempersiapkan cara untuk mengakui } \\
\text { usaha dan prestasi individu maupun } \\
\text { kelompok }\end{array}$ \\
\hline
\end{tabular}




\section{Model Pembelajaran Kooepertif Tipe Numbered Head Together (NHT)}

Pembelajaran kooperatif tipe NHT dikembangkan oleh Spener Kagen. (Mulyo \& Daryanto, 2012) Pada umumnya NHT digunakan untuk melibatkan siswa dalam pengetahuan pemahaman pembelajaran atau mengecek pemahaman siswa terhadap materi pembelajaran.

Tujuan dari NHT adalah memberi kesempatan kepada siswa untuk saling berbagi gagasan dan mempertimbangkan jawaban yang paling tepat. Selain itu untuk meningkatkan kerja sama siswa, NHT juga bisa diterapkan untuk semua mata pelajaran.

Adapaun tujuan yang hendak dicapai dalam pembelajaran NHT, antara lain:

1) Hasil belajar akademik struktural.

2) Pengakuan adanya keragaman.

3) Pengembangan keterampilan sosial.

\section{Langkah-langkah Model Pembelajaran Kooepertif Tipe Numbered Head Together (NHT)}

Penerapan pembelajaran kooperatif tipe NHT merujuk pada konsep Kagen dengan tiga langkah, antara lain (Zubaedi, 2011): 1) Pembentukan kelompok; 2) Diskusi masalah; dan 3) Tukar jawaban antar kelompok.

Langkah-langkah penerapan NHT, (Mulyo \& Daryanto, 2012) yaitu:

1) Guru menyampaikan materi pembelajaran atau permasalahan kepada siswa sesuai kompetensi dasar yang akan dicapai.

2) Guru memberikan kuis secara individual kepada siswa untu mendapatkan skor awal.

3) Guru membagi kelas dalam beberapa kelompok, setiap kelompok terdiri dari 4-5 siswa, setiap anggota kelompok diberi nomor atau nama.

4) Guru mengajukan permasalahan untuk dipecahkan bersama dalam kelompok.

5) Guru mengecek pemahaman siswa dengan menyebutkan salah satu nomor (nama) anggota kelompok utnuk menjawab yang merupakan perwakilan dari kelompok.

6) Guru memfasilitasi siswa dalam membuat rangkuman, mengarahkan dan memberikan penegasan pada akhir pembelajaran.

7) Guru memberikan tes/kuis kepada siswa secara individual.

8) Guru memberi penghargaan kepada kelompok melalui skor penghargaan berdasarkan perolehan nilai peningkatan hasil belajar individual dari skor dasar ke skor kuis selanjutnya.

\section{METODE PENELITIAN}

\section{Jenis Penelitian}

Jenis penelitian ini yaitu penelitian deskriptif kualitatif dan kuantitatif. Dalam penelitian ini, data diperoleh melalui pengisian kuesioner dan tes hasil belajar. Data diambil di SMP Negeri 4 Kota Bima.

\section{Desain Penelian}

Desain penelitian ini terdapat dua variabel, dengan rincian satu variabel bebas dan satu variabel terikat. Variabel bebas dari penelitian ini adalah model 
pembelajaran kooperatif tipe Numbered head together (A). Sedangkan variabel terikatnya adalah minat dan hasil belajar siswa (B). Penelitian ini melibatkan dua kelas yaitu kelas kelompok pembelajaran kooperatif tipe tipe Number Head Together sebagai kelas eksperimen, dan kelas yang diajarkan dengan model pembelajaran yang digunakan guru sebagai kelas kontrol. Pada kedua kelas diberikan materi yang sama yaitu materi himpunan.

\section{Populasi dan Sampel}

\section{Populasi}

Tempat penelitian ini dilaksanakan di SMPN 4 Kota Bima yang terdiri dari dua kelas yang dijadikan sebagai populasi. Populasi adalah keseluruhan objek penelitian, baik hasil menghitung ataupun pengukuran (kuantitatif ataupun kualitatif) dari karakteristik tertentu yang akan dikenai generalisasi (Ali, 2013).

Jaya (2010), menyatakan bahwa "Populasi adalah wilayah generalisasi yang terdiri atas objek/subjek yang memiliki kuantitas dan karakteristik tertentu yang ditetapkan oleh peneliti untuk dipelajari dan kemudian ditarik kesimpulannya". Dengan kata lain, populasi adalah keseluruhan objek yang akan/ingin diteliti (Salim \& Syahrum, 2017). Populasi dalam penelitian ini adalah seluruh siswa kelas VII SMPN 4 Kota Bima 2021.

\section{Sampel}

Adapun sampel dalam penelitian ini adalah kelas yang menjadi tempat menerapkan model pembelajaran. Jaya (2010) menyatakan sampel adalah sebagian dari jumlah dan karakteristik yang dimiliki oleh populasi tersebut. Pengambilan sampel yang dijadikan pada penelitian ini adalah diambil dengan cara acak sederhana yaitu Simple Random Sampling karena pengambilan sampel dari populasi dilakukan secara acak tanpa memperhatikan strata dalam populasi itu.

\section{Instrumen Penelitian}

1. Instrumen Minat Belajar

Instrumen minat belajar dalam penelitian ini berupa kuesioner yang tertidi dari 20 pernyataan yang berisi empat tanggapan (Selalu, Sering, Jarang, Tidak Pernah).

2. Instrumen Tes Hasil Belajar Siswa

Hasil belajar adalah skor yang diperoleh siswa dari tes hasil belajar. Tes untuk mengetahui hasil belajar pada penelitian ini berupa soal-soal yang disusun sesuai indikator yang akan dicapai pada pembelajaran di kelas.

\section{Teknik Pengumpulan Data}

\section{Menyebar Kuesioner Minat Belajar}

Kuesioner diberikan kepada siswa setelah siswa melaksanakan tes hasil belajar. Peneliti memberikan arahan kepada siswa dalam mengisi kuesioner minat belajar. Setelah siswa selesai mengisi kuesioner, siswa diminta untuk mengumpulkan lembar kuesioner yang telah diisi. Kuesioner minat belajar ini bertujuan untuk mengetahui seberapa besar minat siswa terhadap pembelajaran matematika.

\section{Tes Hasil Belajar}

Pengambilan dengan tes data pada penelitian ini yaitu tes hasil belajar. Tes hasil belajar ini bertujuan untuk mengetahui hasil belajar yang telah dicapai oleh siswa di kelas. 


\section{Metode Analisis data}

1. Analisis Data Minat Belajar

Setelah kuesioner diisi oleh siswa dan dikumpulkan, selanjutnya akan dilakukan perhitungan persentase skor setiap aitemnya. Rumus untuk menghitung persentase skornya adalah sebagai berikut :

$$
\begin{aligned}
& A=\text { Jumlah skor terbesar } \\
& B=\text { Jumlah skor terkecil }
\end{aligned}
$$

$$
C=\frac{A-B}{5}
$$

Sehingga diperoleh lima criteria yaitu sebagai berikut,

Sangat Rendah : $\mathrm{B} \leq \mathrm{x}<\mathrm{B}+\mathrm{C}$

$\begin{array}{ll}\text { Rendah } & : B+C \leq x<B+2 C \\ \text { Sedang } & : B+2 C \leq x<B+3 C \\ \text { Tinggi } & : B+3 C \leq x<B+4 C \\ \text { Sangat Tinggi } & : B+4 C \leq x<B+5 C\end{array}$

Dalam penelitian ini, peneliti memberikan skor menggunakan skala Likert untuk setiap aitem pada jawaban siswa.

Tabel 2. Skor Kuesioner Minat Siswa

\begin{tabular}{|l|c|c|}
\hline \multirow{2}{*}{ Jawaban } & \multicolumn{2}{|c|}{ Pernyataan } \\
\cline { 2 - 3 } & Positif & Negatif \\
\hline Sangat Setuju & 5 & 1 \\
\hline Setuju & 4 & 2 \\
\hline Tidak Setuju & 2 & 4 \\
\hline Sangat Tidak Setuju & 1 & 5 \\
\hline
\end{tabular}

2. Analisis Data Hasil Belajar

Setelah koesioner diisi oleh siswa dan dikumpulkan, selanjutnya akan dilakukan perhitungan presentase skor setiap aitem. Rumus untuk menghitung presentase skornya adalah :

$$
\begin{array}{ll}
\text { Sangat Rendah } & : \mathrm{B} \leq \mathrm{x}<\mathrm{B}+\mathrm{C} \\
\text { Rendah } & : \mathrm{B}+\mathrm{C} \leq \mathrm{x}<\mathrm{B}+2 \mathrm{C} \\
\text { Sedang } & : \mathrm{B}+2 \mathrm{C} \leq \mathrm{x}<\mathrm{B}+3 \mathrm{C} \\
\text { Tinggi } & : \mathrm{B}+3 \mathrm{C} \leq \mathrm{x}<\mathrm{B}+4 \mathrm{C} \\
\text { Sangat Tinggi } & : \mathrm{B}+4 \mathrm{C} \leq \mathrm{x}<\mathrm{B}+5 \mathrm{C}
\end{array}
$$

3. Analisis Korelasi

Analisis korelasi pada penelitian ini yaitu korelasi antara minat belajar dengan hasil belajar siswa.

\section{HASIL DAN PEMBAHASAN}

\section{A. Kelayakan Analisis}

Data penelitian ini diambil pada tanggal 01 September $2021 \mathrm{~s} / \mathrm{d} 9$ Oktober 2021 di SMP Negeri 4 Kota Bima. Jumlah subyek yang akan diteliti rencananya adalah 35 siswa. Pada saat data diambil, seluruh siswa hadir dan mengerjakan Kuesioner Minat Belajar dan Tes Hasil Belajar. 


$$
\text { presentase kesertaan }=\frac{35}{35} \times 100 \%=100 \%
$$

Karena prentase lebih dari $80 \%$ maka data layak dianalisis.

\section{B. Deskripsi Data}

Instrumen yang telah disusun yakni kuesioner minat belajar, dan tes hasil belajar siswa diberikan kepada siswa kelas VII B. Berikut hasil pengambilan data yang diperoleh siswa kelas VII-B mengisi instrumen tersebut dan mengumpulkannya.

a) Data Minat Belajar

Tabel 3. Statistik Kuesioner Minat Belajar Siswa

\begin{tabular}{|c|c|}
\hline Statistika & Data \\
\hline Skor Tertinggi & 89 \\
\hline Stkor Terendah & 66 \\
\hline Jangkauan Data & 23 \\
\hline Mean & 77,8 \\
\hline Median & 78 \\
\hline Modus & 81 \\
\hline Simpangan Baku & 6,51 \\
\hline Kuartil I & 72 \\
\hline Kuartil III & 82 \\
\hline Interkuartil & 10 \\
\hline
\end{tabular}

b) Data Hasil Belajar

Tabel 4. Statistik Tes Hasil Belajar Siswa

\begin{tabular}{|c|c|}
\hline Statistika & Data \\
\hline Skor Tertinggi & 99 \\
\hline Stkor Terendah & 21 \\
\hline Jangkauan Data & 78 \\
\hline Mean & 54 \\
\hline Median & 45 \\
\hline Modus & 30 dan 44 \\
\hline Simpangan Baku & 25,22 \\
\hline Kuartil I & 31 \\
\hline Kuartil III & 80 \\
\hline Interkuartil & 49 \\
\hline
\end{tabular}

1. Deskripsi Grafis

a. Minat Belajar

Data dikelompokkan dalam 5 interval, sehingga didapatkan sebagai berikut :

$A=$ Skor Tertinggi $=89$ 


$$
\begin{aligned}
& B=\text { Skor Terendah }=66 \\
& C=\text { Panjang Interval }=\frac{A-B}{5}=\frac{89-66}{5}=4,6 \approx 5
\end{aligned}
$$

Tabel 5. Interprestasi Minat Belajar Siswa

\begin{tabular}{|c|c|}
\hline Rentang & Keterangan \\
\hline $66 \leq<71$ & Sangat Rendah \\
\hline $71 \leq<76$ & Rendah \\
\hline $76 \leq<81$ & Sedang \\
\hline $81 \leq<86$ & Tinggi \\
\hline $86 \leq<91$ & Sangat Tinggi \\
\hline
\end{tabular}

Tabel 6. Distribusi Frekuensi Minat Belajar

\begin{tabular}{|c|c|c|c|c|c|c|}
\hline Interval & Turus & $\boldsymbol{f}$ & $\begin{array}{r}\text { Batas } \\
\text { Bawah }\end{array}$ & $\begin{array}{r}\text { Batas } \\
\text { Atas }\end{array}$ & $\begin{array}{r}\text { Titik } \\
\text { Tengah }\end{array}$ & $f \mathrm{k}$ \\
\hline $66-70$ & \|\|\|\| & 5 & 65,5 & 70,5 & 68 & 5 \\
\hline $71-75$ & \|\|\|\|$\|$ & 9 & 70,5 & 75,5 & 73 & 14 \\
\hline $76-80$ & \|\|\|\| & 7 & 75,5 & 80,5 & 78 & 21 \\
\hline $81-85$ & \|\|\|\|$\|$ & 9 & 80,5 & 85,5 & 83 & 30 \\
\hline $86-90$ & \|\|$\|$ & 5 & 85,5 & 90,5 & 88 & 35 \\
\hline
\end{tabular}

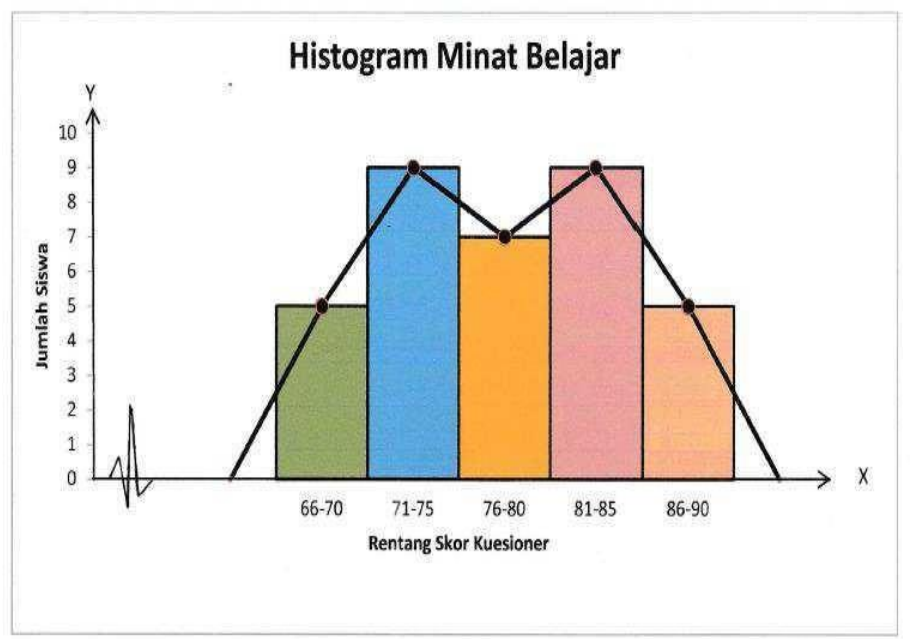

Gambar 1. Histogram Minat Belajar

b. Hasil Belajar

Data dikelompokkan dalam 5 interval, sehingga didapatkan sebagai berikut :

$A=$ Skor Tertinggi $=99$

$B=$ Skor Terendah $=21$ 


$$
C=\text { Panjang Interval }=\frac{A-B}{5}=\frac{99-21}{5}=15,6 \approx 16
$$

Tabel 7. Interprestasi Minat Belajar Siswa

\begin{tabular}{|c|c|}
\hline Rentang & Keterangan \\
\hline $66 \leq<71$ & Sangat Rendah \\
\hline $71 \leq<76$ & Rendah \\
\hline $76 \leq<81$ & Sedang \\
\hline $81 \leq<86$ & Tinggi \\
\hline $86 \leq<91$ & Sangat Tinggi \\
\hline
\end{tabular}

Tabel 4.8. Distribusi Frekuensi Minat Belajar

\begin{tabular}{|c|c|c|c|c|c|c|}
\hline Interval & Turus & $f$ & $\begin{array}{r}\text { Batas } \\
\text { Bawah } \\
\end{array}$ & $\begin{array}{r}\text { Batas } \\
\text { Atas } \\
\end{array}$ & $\begin{array}{r}\text { Titik } \\
\text { Tengah } \\
\end{array}$ & $f \mathrm{k}$ \\
\hline $66-70$ & \|\|$\|$ & 5 & 65,5 & 70,5 & 68 & 5 \\
\hline $71-75$ & ||||| ||| & 9 & 70,5 & 75,5 & 73 & 14 \\
\hline $76-80$ & \|\||||| & 7 & 75,5 & 80,5 & 78 & 21 \\
\hline $81-85$ & ||||| |||| & 9 & 80,5 & 85,5 & 83 & 30 \\
\hline $86-90$ & \|\|$\|$ & 5 & 85,5 & 90,5 & 88 & 35 \\
\hline
\end{tabular}

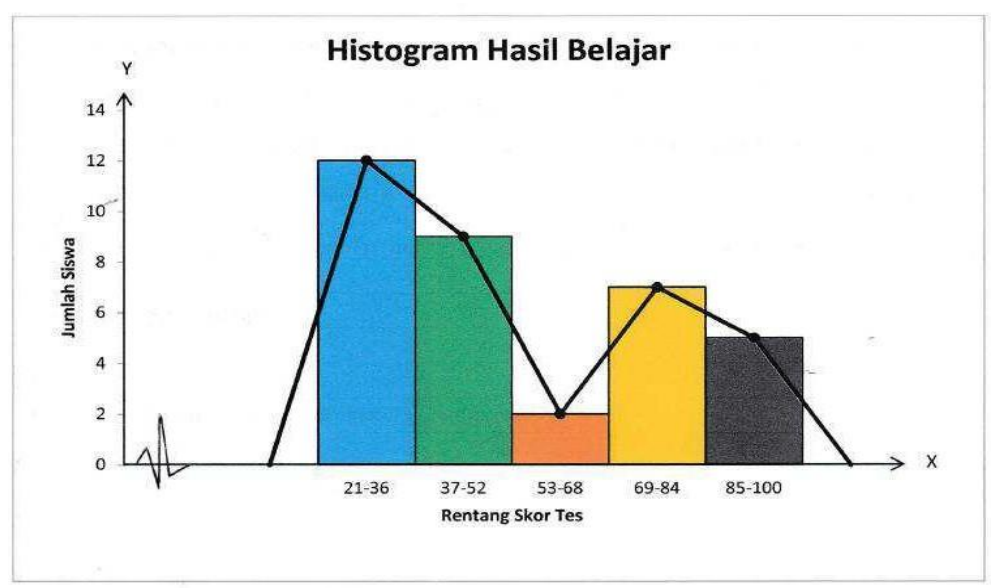

Gambar 2. Histogram Hasil Belajar

\section{Statistik Inferensial}

Untuk mengetahui ada tidaknya hubungan antara minat belajar terhadap hasil belajar siswa maka data yang diperoleh akan diuji korelasinya dan uji regresi. Sebagai syarat untuk menguji korelasi, dilakukan uji normalitas terlebih dahulu untuk mengetahui data berdistribusi normal atau tidak. 


\section{Uji Normalitas}

a. Uji Normalitas Data Minat Belajar

Hipotesis

$H_{0}$ : Data minat belajar berdistribusi normal

$H_{1}$ : Data minat belajar tidak berdistribusi normal

Taraf signifikasi $(\alpha)=0,05$

Daerah penolakan : $H_{0}$ ditolak apabila $d_{\text {maks }}>d_{\text {tabel }}$

\section{Statistik}

$$
\begin{aligned}
& d_{\text {maks }}=0,070 \\
& d_{\text {tabel }}=0,334
\end{aligned}
$$

Kesimpulan :

Karena $\quad d_{\text {maks }}=0,070<d_{\text {tabel }}=0,334$ maka $H_{0}$ diterima, sehingga data minat belajar siswa berdistribusi normal.

b. Uji Normalitas Data Hasil Belajar

\section{Hipotesis}

$H_{0}$ : Data minat belajar berdistribusi normal

$H_{1}$ : Data minat belajar tidak berdistribusi normal

Taraf signifikasi $(\alpha)=0,05$

Daerah penolakan : $H_{0}$ ditolak apabila $d_{\text {maks }}>d_{\text {tabel }}$

\section{Statistik}

$$
\begin{aligned}
& d_{\text {maks }}=0,151 \\
& d_{\text {tabel }}=0,334
\end{aligned}
$$

Kesimpulan :

Karena $\quad d_{\text {maks }}=0,151<d_{\text {tabel }}=0,334$ maka $H_{0}$ diterima, sehingga data minat belajar siswa berdistribusi normal.

\section{Uji Korelasi}

a. Uji Korelasi Antara Minat dan Hasil Belajar

\section{Hipotesis}

$\mathrm{H}_{0}$ : Tidak ada korelasi positif antara minat dan hasil belajar siswa

$\mathrm{H}_{1}$ : Ada korelasi positif antara minat dan hasil belajar siswa

Taraf signifikasi $(\alpha)=0,05$

Daerah penolakan : $H_{0}$ ditolak apabila $r_{h i t u n g} \geq r_{\text {tabel }}$

\section{Statistik}

$$
\begin{aligned}
r_{\text {hitung }} & =0,142 \\
r_{\text {tabel }} & =0,334
\end{aligned}
$$

Kesimpulan :

Karena $r_{\text {hitung }}=0,142<r_{\text {tabel }}=0,334$ maka $\mathrm{H}_{0}$ diterima, sehingga tidak ada korelasi positif antara minat dan hasil belajar.

\section{Pembahasan}

\section{Minat Belajar Siswa}

Berdasarkan hasil pengisian kuesioner minat belajar diketahui bahwa 5 siswa memiliki minat belajar sangat tinggi, 9 siswa memiliki minat belajar tinggi, 7 siswa memiliki minat belajar sedang, 9 siswa memiliki minat belajar rendah, dan 5 siswa 
memiliki minat belajar sangat rendah. Dengan demikian dapat disimpulkan bahwa minat belajar siswa kelas VII-B SMP Negeri 4 Kota Bima masuk dalam kategori tinggi, karena jumlah siswa yang masuk dalam kategori bermotivasi sangat tinggi, tinggi, dan sedang adalah $60 \%$ dari total keseluruhan 35 siswa.

2. Tes Hasil Belajar Siswa

Berdasarkan tes hasil belajar diketahui bahwa 5 siswa memiliki hasil belajar sangat tinggi, 7 siswa memiliki hasil belajar tinggi, 2 siswa memiliki hasil belajar sedang, 9 siswa memiliki hasil belajar rendah, dan 12 siswa memiliki hasil belajar sangat rendah. Dengan demikian dapat disimpulkan bahwa hasil belajar siswa kelas VII-B SMP Negeri 4 Kota Bima masuk dalam kategori rendah, karena jumlah siswa yang masuk dalam kategori bermotivasi rendah dan sangat rendah adalah $60 \%$ dari total keseluruhan 35 siswa.

3. Korelasi antara Minat Belajar dan Hasil Belajar Siswa

Berdasarkan perhitungan yang telah dilakukan, koefisien korelasi yang diperoleh sebesar 0,142. Hal ini menunjukkan ada korelasi antara minat belajar siswa terhadap hasil belajar siswa tetapi tidak signifikan. Kontribusi minat belajar terhadap hasil belajar yang diperoleh adalah $0,142^{2}=0,020164$ a tau $2,0164 \%$ sedangkan sisanya 97,9836\% dipengaruhi faktor lain seperti bakat, intelegensi, keterampilan, maupun lingkungan yaitu keluarga, sekolah, dan lingkungan masyarakat.

\section{KESIMPULAN}

Berdasarkan penelitian yang telah dilakukan di kelas VII-B SMP Negeri 4 Kota Bima, maka dapat disimpulkan bahwa: 1) Berdasarkan hasil pengisian kuesioner minat belajar diketahui bahwa 5 siswa memiliki minat belajar sangat tinggi, 9 siswa memiliki minat belajar tinggi, 7 siswa memiliki minat belajar sedang, 9 siswa memiliki minat belajar rendah, dan 5 siswa memiliki minat belajar sangat rendah. Dengan demikian dapat disimpulkan bahwa minat belajar siswa kelas VII-B SMP Negeri 4 Kota Bima masuk dalam kategori tinggi, karena jumlah siswa yang masuk dalam kategori bermotivasi sangat tinggi, tinggi, dan sedang adalah $60 \%$ dari total keseluruhan 35 siswa; 2) Berdasarkan tes hasil belajar diketahui bahwa 5 siswa memiliki hasil belajar sangat tinggi, 7 siswa memiliki hasil belajar tinggi, 2 siswa memiliki hasil belajar sedang, 9 siswa memiliki hasil belajar rendah, dan 12 siswa memiliki hasil belajar sangat rendah. Dengan demikian dapat disimpulkan bahwa hasil belajar siswa kelas VII-B SMP Negeri 4 Kota Bima masuk dalam kategori rendah, karena jumlah siswa yang masuk dalam kategori bermotivasi rendah dan sangat rendah adalah 60\% dari total keseluruhan 35 siswa; dan 3) Berdasarkan perhitungan yang telah dilakukan, koefisien korelasi yang diperoleh sebesar 0,142. Hal ini menunjukkan ada korelasi antara minat belajar siswa terhadap hasil belajar siswa tetapi tidak signifikan. Kontribusi minat belajar terhadap hasil belajar yang diperoleh adalah $0,142^{2}=0,020164$ atau 2,0164\%.

\section{DAFTAR PUSTAKA}

Ali, M. (2013). Statistic Penelitian Pendidikan. Yogyakarta: Patama Publishing.

Jaya. (2010). Statistik Penelitian Untuk Pendidikan. Medan: Cita Pustaka.

Mudjiono \& Dimyati. (2006). Belajar dan Pembelajaran. Jakarta: PT Rineka Cipta

@ 2021 DIKSI (https://jurnal.bimaberilmu.com/index.php/diksi) 
Muhlisrarini \& Ali, (2014). Perencanaan Dan Strategi Pembelajaran Matematik. Jakarta: PT Raja Grafindo Persda.

Mulyo \& Daryanto. (2012). Model Pembelajaran Inovatif. Yogyakarta: Gava Media.

Salim \& Syahrum. (2017). Metodologi Penelitian Kuantitatif. Bandung: Citapustaka Media.

Sanjaya, W. (2011). Pembelajaran dalam Implementasi Kurikulum Berbasis Kompetensi. Jakarta: Kencana.

Susanto, A. (2013). Teori Belajar dan Pembelajaran di Sekolah Dasar. Jakarta: Kencana.

Winkel, (1983). Psikologi Pengajaran. Jakarta: PT Gramedia.

Zubaedi. (2011). Desain PendidikanKarakter. Jakarta: Kencana. 